Vol.45, Special n. : pp. 9-14, September 2002 ISSN 1516-8913 Printed in Brazil

\title{
Radionuclide Imaging of the Painful Joint Replacement: Past, Present and Future
}

\author{
Christopher Palestro* \\ Long Island Jewish Medical Center; palestro@lij.edu; New Hyde Park-NY - USA
}

\begin{abstract}
Differentiating aseptic loosening from infection as the cause of prosthetic joint failure is difficult because both entities are similar, clinically and histopathologically. Aseptic loosening frequently results from an immune reaction to the prosthesis. There is inflammation with an influx of histiocytes, giant cells, lymphocytes, and plasma cells. Proinflammatory cytokines and proteolytic enzymes are secreted, causing osteolysis and loosening. These same events occur in infection except that neutrophils, rarely present in aseptic loosening, are invariably present in infection. Clinical signs and symptoms, laboratory tests, $x$-rays and joint aspiration are insensitive, nonspecific or both. Artifacts produced by the metallic hardware hamper cross-sectional imaging modalities. Radionuclide imaging is not affected by the presence of metallic hardware and is very useful for evaluating the painful prosthesis. Bone scintigraphy, with an accuracy of $50 \%-70 \%$ is a useful screening test, since a normal study effectively excludes a prosthetic complication. Adding gallium-67, a nonspecific inflammation-imaging agent, improves the accuracy of bone scintigraphy to $70 \%-80 \%$. The accuracy of combined leukocyte/marrow imaging, $90 \%$, is the highest among available radionuclide studies. Its success is due to the fact that leukocyte imaging is most sensitive for detecting neutrophil mediated inflammations. Inflammatory conditions that are neutrophil-poor, even though large numbers of other leukocytes may be present, (such as the aseptically loosened joint prosthesis) go undetected. The success of leukocyte/marrow imaging is tempered by the limitations of in-vitro labeling. In-vivo labeling has been investigated and a murine monoclonal antigranulocyte antibody appears promising. Some investigations have focused on F-18 FDG imaging, although specificity is a concern with this agent.
\end{abstract}

Key words: Radionuclide imaging, painful joint replacement, infection

\section{INTRODUCTION}

Although attempts at joint replacement surgery were sporadically carried out in the nineteenth century modern joint arthroplasty began in earnest in the second half of the twentieth century. Sir John Charnley developed the predecessors of today's hip replacements during the late 1950's and early 1960's. Modern day hip prostheses, known as modular because the surgeon can modify the different components to suit an individual patient's needs, are made up of metal, cobalt chromium and titanium, and plastic, ultrahigh molecular-weight (UHMW) polyethylene. These components can be attached to the native bone in a variety of ways. In the case of cemented devices, surgical cement, polymethylmethacrylate (PMMA), secures the hardware. Fixation of the cementless, porous coated, prosthesis is accomplished through bony ingrowth which interdigitates into a porous coating applied to the surface of the device. In another type, bonding is

\footnotetext{
* Author for correspondence
} 
accomplished through the application of a hydroxyapatite compound to the surface of the components that stimulates new bone formation and serves as an attachment for newly formed osseous tissue around the hardware. Acetabular components can also be forced, or press -fit, into the acetabulum and, if needed, can be further secured with orthopedic screws.

The prototype of the modern knee replacement, known as the total condylar knee replacement, was developed at the Hospital for Special Surgery in New York City, in the mid 1970's under the leadership of Dr. John N. Insall. The mobilebearing prosthesis in use today affords improved joint mobility with less polyethylene breakdown than its fixed-bearing predecessor.

More than 400,000 hip and knee arthroplasties are performed annually in the United States; by the year 2030, this number may exceed 700,000. Despite its success, joint replacement surgery is not without complications including aseptic loosening, dislocation, fracture, and infection. Many of these complications can be readily diagnosed and treated. Differentiating infection from aseptic loosening, the most frequent complication of joint replacement surgery, is more difficult, however, because the clinical presentation of, and the histopathologic changes in, both entities are remarkably similar.

Aseptic loosening: By ten years after implantation, $50 \%$ of prostheses demonstrate radiographic evidence of loosening, and 30\% require revision. While prosthetic design and technical factors are responsible in some cases, a significant number of cases of aseptic loosening are the result of an inflammatory/ immune reaction. Histopathologic examinations of failed prostheses show a synovial like pseudomembranous structure that develops at the cement/bone interface. The cellular composition of the pseudomembrane is varied: histiocytes are seen most frequently $(95 \%$ of specimens), followed by giant cells $(80 \%)$, and lymphocytes and plasma cells (25\%). Neutrophils are present in less than $10 \%$ of the cases. Particulate debris, produced by component fragmentation, attracts and activates tissue phagocytes normally present around the prosthesis. Because this debris is impervious to regular enzymatic destruction, the degradative function of the inflammatory cells is frustrated, leading to repeated, but unsuccessful, attempts at phagocytosis. These attempts at phagocytosis stimulate secretion of proinflammatory cytokines and proteolytic enzymes that damage bone and cartilage and activate immune cells. The heightened inflammatory response leads to osteolysis, which results in loss of suppo rting osseous tissues and, eventually, loosening of the prosthesis.

Infection: The rate of infection following primary implantation is about $1 \%$ for hip and $2 \%$ for knee prostheses. The rate of infection following revision surgery is somewhat higher: about 3\% for hip and $5 \%$ for knee replacements. One third of these infections develop within three months, another third within one year, and the remainder more than one year after surgery. Histopathologically, the inflammatory reaction accompanying the infected prosthesis is identical to that present in aseptic loosening, with one important difference: neutrophils, usually absent in aseptic loosening, are invariably present in large numbers in infection.

It is extremely important to be able to differentiate aseptic loosening from infection, because the treatment of these two entities is radically different. In aseptic loosening, the patient typically undergoes a single stage revision arthroplasty. The treatment of infected hardware, on the other hand, is more complex. An excisional arthroplasty, or removal of the prosthesis, is performed, followed by a protracted course of antimicrobial therapy. Eventually, the patient undergoes a revision arthroplasty.

To be useful, therefore, a diagnostic test must be specific as well as sensitive. A test that is sensitive but not specific can lead to multiple, costly, operations in many patients in whom a single intervention may have sufficed. Similarly, the specific, but insensitive, test will also result in additional surgical intervention, because undiagnosed infection will cause any revision implant to fail. Nonspecific markers of inflammation such as the erythrocyte sedimentation rate and $\mathrm{C}$-reactive protein level may be elevated in both loosening and infection. The results of joint aspiration have been disappointing with large numbers of false positive and false negative results having been reported. Plain radiographs are neither sensitive nor specific and the artifacts caused by the hardware itself limit cross-sectional imaging modalities, such as computed tomography and magnetic resonance imaging. Radionuclide imaging, which reflects 
physiologic rather than anatomic changes, and is not hindered by the metallic hardware is the current imaging modality of choice for evaluati on of suspected joint replacement infection.

\section{RADIONUCLIDE IMAGING}

\section{Bone Scintigraphy}

Although most investigators agree that a normal radionuclide bone study is strong evidence against a prosthetic abnormality, the significance of increased periprosthetic uptake, however, is less certain. For hip prostheses, diffusely increased periprosthetic uptake is often equated with infection. The accumulation of bone-seeking tracers such as ${ }^{99 \mathrm{~m}} \mathrm{Tc}-\mathrm{MDP}$, which localize on the surface of the bone mineral matrix, is dep endent on blood flow and on the rate of new bone formation. Consequently any cause of accelerated new bone formation may result in increased periprosthetic activity on bone images. The diffuse pattern seen with infection is probably due to generalized osteolysis, which is also present in aseptic loosening secondary to inflammation. Scintigraphically, then, these two entities may be indistinguishable. The introduction of porous coated prostheses has further complicated the analysis of the bone image. These devices were designed, for stabilization purposes, to stimulate bony ingrowth; hence, periprosthetic uptake patterns are more variable than those associated with the cemented variety. Focal uptake at the distal tip of the femoral component of a cemented device more than one year old is often attributed to aseptic loosening. In the case of the porous coated prosthesis, however, this pattern is often present in asymptomatic individuals for a considerably longer time after surgery.

Periprosthetic uptake patterns around knee prostheses are even more variable than those around hip prostheses, with large numbers of asymptomatic patients demonstrating persistent periprosthetic activity for several years after implantation.

To further complicate matters, about two -thirds of all joint replacement infections occur during the first year after implantation, when, regardless of the type or location of the prosthesis, periprosthetic uptake is so variable that only a normal bone scan contributes useful information. The overall accuracy of radionuclide bone imaging in the evaluation of the prosthetic joint is about 50 $70 \%$. In spite of this, since it has a high negative predictive value, bone imaging is useful as an initial screening test.

\section{Sequential Bone/Gallium Imaging}

In an effort to improve the specificity of bone scintigraphy, complementary gallium imaging is often performed. Over time a standardized method of interpreting sequential bone/gallium images has evolved. The combined study is:

Negative for infection when gallium images are normal, regardless of the bone scan findings, or when the spatial distribution of the two tracers is congruent and the relative intensity of gallium uptake is less than that of the bone tracer.

Positive for infection when the distribution of the two radiotracers is spatially incongruent or when their distribution is spatially congruent and the intensity of gallium uptake exceeds that of the bone agent.

Equivocal for infection when the distribution of the two tracers is spatially congruent and the relative intensity of uptake of each tracer is similar.

Gallium uptake is related to inflammation in general and not to infection specifically. Consequently, with an overall accuracy of about $70 \%-80 \%$, this technique is not well suited for distinguishing the inflamed, aseptically loosened prosthesis from the infected prosthesis.

\section{Labeled Leukocyte Scintigraphy}

Uptake of labeled leukocytes depends on intact chemotaxis, the number and types of cells labeled, and the principal cellular component of a $g$ iven inflammatory response. In the typical clinical setting the majority of cells labeled are neutrophils. Hence, the procedure is most useful for detecting neutrophil-mediated inflammatory processes. This, at least theoretically, makes labeled leukocyte imaging particularly well suited for distinguishing between the inflamed aseptically loosened prosthesis, in which neutrophils are generally absent, from the infected prosthesis, in which neutrophils are present. The results of early studies, however, varied widely on the accuracy of this technique for diagnosing the infected prosthesis. Low sensitivity was attributed to "chronicity" of the process, while low specificity was attributed to "inflammation". The paucity of 
neutrophils in the aseptically loosen ed prosthesis, and the invariable presence of these cells in the setting of infected hardware, would suggest, however, that there is another explanation for the inconsistent results.

Interpretation of labeled leukocyte images entails a comparison of activity in the region of interest to activity in some predefined normal reference point. In the case of prostheses, periprosthetic activity is often compared with adjacent bone activity or with activity in the corresponding contralateral extremity. Increased periprosthetic activity compared to the reference point is generally interpreted as positive for infection. Labeled leukocytes accumulate not only in infection but in the bone marrow as well. Historically, hematopoietically active marrow in adults has been assumed to be limited to the axial skeleton and proximal appendicular skeleton, with any labeled leukocyte activity outside this distribution ascribed to infection. The distribution of hematopoietically active marrow extremely variable, and is affected by many conditions including tumors, fractures, hemolytic anemias, and even orthopedic hardware. Clearly then, the explanation for the inconsistent results reported for labeled leukocyte imaging is an inability to distinguish uptake of labeled leukocytes in infection from uptake in aberrantly located, but otherwise normal, marrow.

Performing bone marrow imaging with Tc-99m sulfur colloid has circumvented this problem. Both labeled leukocytes and sulfur colloid accumulate in the bone marrow, but only labeled le ukocytes accumulate in infection. Thus, on combined labeled leukocyte/ marrow imaging, when the distribution of the two tracers is similar, or spatially congruent, the labeled leukocyte activity is due to the presence of marrow. When there is activity on the labeled leukocyte images without corresponding activity on sulfur colloid images, labeled leukocyte uptake is due to infection. The results of combined leukocyte/marrow imaging of prosthetic joints have been uniformly excellent with an accuracy of $90 \%$ or greater. Data from our own institution suggest that the sensitivity of the study is not affected by antibiotic therapy.

\section{Investigational Agents}

Leukocyte/marrow scintigraphy, though extremely accurate, is hampered by significant limitations and several methods of labeling leukocytes in-vivo have been investigated, including peptides and antigranulocyte antibodies/antibody fragments. The only such agent currently under active investigation in the U.S.A. is a ${ }^{99 \mathrm{~m}}$ Tc-labeled murine IgM monoclonal antibody, which binds with a very high affinity to CD-15 receptors present on the surface membrane of human polymorphonuclear leukocytes. Accumulation of this agent at sites of infection is probably due to binding of the antibody to circulating neutrophils which subsequently migrate to the nidus of infection, as well as to diffusion of the antibody across capillary membranes with subsequent binding to neutrophils already sequestered in a focus of infection. Data from our own institution suggest that this agent may be a suitable alternative to the in-vitro labeled leukocyte procedure, although optimal imaging times and the need for complementary marrow imaging have yet to be determined.

There are data that suggest that ${ }^{18} \mathrm{FDG}$ is useful for detecting musculoskeletal infection. Any process that involves increased cellular respiration, as seen in infection, inflammation, reparative state, or tumors, is expected to show increased activity on FDG-PET imaging. One group of investigators has recently reported that although the technique is very accurate for detecting infected hip prostheses false positive results were encountered in the evaluation of knee prostheses. Our own experience suggests that the technique cannot distinguish the inflamed aseptically loosened prosthesis fr om the infected one, regardless of the location. This is not surprising when one considers that FDG uptake is dependent on tissue metabolism. Inflammation and infection are both hypermetabolic states and will therefore be manifest as areas of increased activity.

\section{CONCLUSION}

While many of the complications of joint replacement surgery can be easily diagnosed and treated, differentiating aseptic loosening from infection remains a daunting task. The relationship between aseptic loosening and inflammation makes nonspecific indicators of inflammation of limited utility. Despite its not insignificant limitations, combined leukocyte/marrow scintigraphy remains the procedure of choice for diagnosing the infected joint replacement. To be successful, future investigations will need to 
continue to focus on methods of labeling neutrophils in-vivo, or, perhaps, on developing bacteria-specific tracers.

\section{RESUMO}

É difícil diferenciar o afrouxamento asséptico do infeccioso como causa da falência de uma prótese articular pois ambas as entidades são similares clinica e histopatologicamente. $\mathrm{O}$ afrouxamento asséptico frequentemente resulta de uma reação imune à prótese. Há inflamação com o influxo de histiócitos, células gigantes, linfócitos e plasmócitos. Citocinas pró-inflamatórias e enzimas proteolíticas são secretadas causando osteólise e afrouxamento. Estes mesmos eventos ocorrem na infecção, exceto que os neutrófilos raramente presentes no afrouxamento, estão invariavelmente presentes na infecção. Os sinais e sintomas clínicos, os testes laboratoriais, radiografias e aspirados da articulação não apresentam sensibilidade, especificidade ou ambos. Artefatos produzidos pelos aparelhos metálicos dificultam as imagens cross-seccionais. A imagem com radionuclídeos não é afetada pela presença de aparelhos metálicos e é muito útil para avaliação de próteses dolorosas. A cintigrafia óssea, com uma acurácia de 50 a $70 \%$ é um teste valioso de rastreamento, desde que um resultado normal exclui complicações da prótese. Com o gálio -67, um agente não-específico para imagens inflamatórias, há uma melhora de 70 a $80 \%$ na acurácia da cintigrafia óssea. A acurácia de $90 \%$ resultante da combinação de imagens leucócito/medula óssea é uma das mais altas existentes entre os estudos disponíveis com radionuclídeos. Seu sucesso é devido ao fato que a imagem com leucócitos é mais sensível para detectar inflamações mediadas por neutrófilos. As condições inflamatórias com poucos neutrófilos, mesmo que outros leucócitos possam estar presentes em grande quantidade (tais como no afrouxamento asséptico das próteses articulares), seguem indectáveis. $O$ sucesso da imagem leucócito/medula óssea é moderado por limitações na marcação in-vitro. Parece ser promissora a marcação in-vivo com anticorpos murinos monoclonais anti-granulócitos. Alguns trabalhos têm sido direcionados para a imagem com F-18 FDG, embora a especificidade seja uma problema com este agente.

\section{REFERENCES}

Ashbrooke, A. B. and Calvert, P. T. (1990), Bone scan appearances after uncemented hip replacement. $J$. Royal Soc. Med., 83, 768-769.

Daniels, A. U.; Tooms, R. E. and Harkess, J. W. (1998), Arthroplasty: Introduction and overview. In- Canale ST (ed). Campbell's Operative Orthopaedics ( $9^{\text {th }}$ ed.). St. Louis, Mosby. pp. 211-227.

Della Valle, C. J.; Bogner, E. and Desai, P. et al. (1999), Analysis of frozen sections of intraoperative specimens obtained at the time of reoperation after hip or knee resection arthroplasty for the treatment of infection. J. Bone \& Joint Surg., 81-A, 684-689.

Feldman, D. S.; Lonner, J. H.; Desai, P. and Zuckerman, J. D. (1995), The role of intraoperative frozen sections in revision total joint arthroplasty. $J$. Bone \& Joint Surg., 77-A, 1807-1813.

Guyton, J. L. (1998), Arthroplasty of ankle and knee. In- Canale ST (ed).Campbell's Operative Orthopaedics ( $9^{\text {th }}$ ed.). St Louis, Mosby. pp. 232- 285.

Hanssen, A. D. and Rand, J. A. (1998), Evaluation and treatment of infection at the site of a total hip or knee arthroplasty. J. Bone \& Joint Surg., 80-A, 910-922.

Harkess, J. W. (1998), Arthroplasty of hip. In- Canale ST (ed). Campbell's Operative Orthopaedics $\left(9^{\text {th }}\right.$ ed.). St Louis, Mosby. pp. 296- 456.

Harris, W. H. and Sledge, C. B. (1990), Total hip and total knee replacement (Part I). N. Engl. J. Med., 323, 725-731.

Harris, W. H. and Sledge, C. B. (1990), Total hip and total knee replacement (Part II). N. Engl. J. Med., 323, 801-807.

Love, C.; Tomas, M. B.; Marwin, S. E. and Palestro, C. J. (2002), The Effect of Antibiotic Therapy on the Sensitivity of Combined Labeled Leukocyte/Marrow Imaging of Suspected Prosthetic Joint Infection. $J$. Nucl. Med., 44, (P)82.

Love, C.; Tomas, M. B.; Marwin, S. E. and Palestro, C. J. (2002), Improving the Specificity of ${ }^{18}$ F-FDG Imaging of Painful Joint Prostheses. J. Nucl. Med., 44, (P)126.

Love, C.; Tomas, M. B.; Marwin, S. E.; Pugliese, P. V. and Palestro, C. J. (2001), Role of Nuclear Medicine in Diagnosis of the Infected Joint Replacement. RadioGraphics, 21, 1229-1238.

Maloney, W. J. and Smith, R. L. (1995), Periprosthetic osteolysis in total hip arthroplasty: the role of particulate wear debris. J. Bone Joint Surg., 77-A, 1448-1461.

National Institute of Health. Deep Infections of Total Joint Replacement. (Dec. 1999), PA Number PA-00-014.

Palestro, C. J. (1994), Musculoskeletal infection. InFreeman LM (ed) Nuclear Medicine Annual 1994. New York, Raven Press. pp. 91-119. 
Palestro, C. J. and Torres, M. A. (1997), Radionuclide imaging in orthopedic infections. Sem. Nucl. Med., 27, 334-345.

Palestro, C. J.; Kim, C. K.; Swyer, A. J. et al. (1990), Total hip arthroplasty: periprosthetic indium-111labeled leukocyte activity and complementary technetium-99m-sulfur colloid imaging in suspected infection. J. Nucl. Med., 31, 1950-1955.

Palestro, C. J.; Kipper, S. L.; Weiland, F. L.; Love, C. and Tomas, M. B. (2002), Diagnosing Osteomyelitis with a Technetium-99m Labeled Anti-Granulocyte Antibody: Comparison with Indium-111-Labeled Leukocytes-Initial Results. Radiology, 223, 758-764.

Palestro, C. J.; Swyer, A. J.; Kim, C. K. and Goldsmith, S. J. (1991), Infected knee prostheses: diagnosis with In-111 leukocyte, Tc-99m sulfur colloid, and Tc-99m MDP imaging. Radiology, 179, 645-648.

Seabold, J. E.; Palestro, C. J. and Brown, M. L. et al. (1997), Society of Nuclear Medicine Procedure Guideline For Gallium Scintigraphy in Inflammation. Soc. Nucl. Med. Procedure Guidelines Manual, 75-78.

Spangehl, M. J.; Masri, B. A.; O'Connell, J. X. and Duncan, C.P. (1999), Prospective analysis of preoperative and intraoperative investigations for the diagnosis of infection at the sites of two hundred and two revision total hip arthroplasties. J. Bone \& Joint Surg., 81-A, 672-683.
Spanghel, M. J.; Younger, A. S.; Masri, B. A. and Duncan, C. P. (1997), Diagnosis of infection following total hip arthroplasty. J. Bone \& Joint Surg., 79-A, 1578-1588.

Tobin, E. H. (1999), Prosthetic joint infections: controversies and clues. Lancet, 353, 770-771.

Toumbis, C. A.; Kronick, J. L.; Wooley, P. H. and Nasser, S. (1997), Total joint arthroplasty and the immune response. Sem. Arth. \& Rheum., 27, 44-47.

Tsukayama, D. T.; Estrada, R. and Gustilo, R. B. (1996), Infection after total hip arthroplasty. J. Bone \& Joint Surg., 78-A, 512- 523.

Wooley, P. H.; Nasser, S. and Fitzgerald Jr., R. H. (1996), The immune response to implant materials in humans. Clin. Orthop., 326, 63-70.

Zhuang H, Duarte PS, Pourdehnad M, et al. (2001), The promising role of ${ }^{18} \mathrm{~F}-\mathrm{FDG}$ PET in detecting infected lower limb prosthesis implants. J. Nucl. Med., 42, 44-48. 